Cornell University Law School Scholarship@Cornell Law: A Digital Repository

\title{
On the Proper Motives of Corporate Directors (or, Why You Don't Want to Invite Homo Economicus to Join Your Board)
}

Lynn A. Stout

Cornell Law School,1s483@cornell.edu

Follow this and additional works at: http://scholarship.law.cornell.edu/facpub

Part of the Behavioral Economics Commons, Corporation and Enterprise Law Commons, and the Law and Economics Commons

\section{Recommended Citation}

Stout, Lynn A., "On the Proper Motives of Corporate Directors (or, Why You Don't Want to Invite Homo Economicus to Join Your Board)" (2003). Cornell Law Faculty Publications. Paper 763.

http://scholarship.law.cornell.edu/facpub/763 


\title{
ON THE PROPER MOTIVES OF CORPORATE DIRECTORS (OR, WHY YOU DON'T WANT TO INVITE HOMO ECONOMICUS TO JOIN YOUR BOARD)
}

\author{
BY LYNN A. STOUT
}

\begin{abstract}
One of the most important questions in corporate governance is how directors of public corporations can be motivated to serve the interests of the firm. Directors frequently hold only small stakes in the companies they manage. Moreover, a variety of legal rules and contractual arrangements insulate them from liability for business failures. Why then should we expect them to do a good job?

Conventional corporate scholarship has great difficulty wrestling with this question, in large part because conventional scholarship usually adopts the economist's assumption that directors are rational actors motivated purely by self-interest. This homo economicus model of behavior may be fundamentally misleading when applied to corporate directors. The institution of the corporate board is premised on the expectation, and the experience, of director altruism, in the form of a sense of obligation to the firm and its shareholders. As a result, to properly understand the role and conduct of corporate directors, we must take into account the empirical phenomenon of altruism.

One potential starting point for such a project can be found in the extensive evidence that has been developed over the past four decades on altruism among strangers in experimental games. This evidence demonstrates that altruistic behavior is in fact quite common. More important, it is predictable. A variety of factors can reliably increase, or decrease, the incidence of altruism observed in experimental games. These results may offer a foundation for building a model of human behavior that is both more accurate and more useful than the homo economicus model. They also carry important implications for how we select, educate, regulate, and compensate corporate directors.
\end{abstract}

'Professor of Law, University of California at Los Angeles School of Law. An earlier version of this essay was presented on October 19, 2001, as the 17th Annual Francis G. Pileggi Distinguished Lecture in Law at the Widener University School of Law. I would like to thank those who offered their comments and questions on that occasion for their useful insights. I am also indebted to Bill Allen, Iman Anabtawi, Steve Bainbridge, Stuart Banner, Caroline Gentile, Bill Klein, Jack Jacobs, Lynn LoPucki, Douglas Olin, Francis Pileggi, and Leo Strine for their advice and suggestions. 
At the close of 2001, the book value of the assets held by U.S. nonfinancial business corporations totaled nearly $\$ 18$ trillion. ${ }^{1}$ Book value is an infamously incomplete and inexact measure of real worth. Nevertheless, if this figure is at all related to actual value, the economic value of the assets controlled by Corporate America today can be measured at least in the tens of trillions of dollars.

Who controls those tens of trillions of dollars? It is a basic tenet of U.S. corporate law that corporate assets are ultimately controlled by boards of directors. ${ }^{2}$ In a typical case, this means a company's assets are managed by a handful of individuals who may collectively hold very little of the company's equity and debt, who may have full-time positions and responsibilities at other firms or institutions, who may be scattered around the country, and who may only meet to deliberate on the company's future a half-dozen times a year. These are the people who are in charge of those tens of trillions of dollars, as a matter of law, and (in most large public firms, at least) as a matter of fact.

Twenty years ago, this statement might have provoked some readers to protest: "That's not right. It's not the directors who control the corporation. It's the Chief Executive Officer(CEO). The directors are only the CEO's puppets: he picked them, and they'll do his bidding." Twenty years ago, this might have been true. It is not nearly so true today. Today, if we look at the larger public firms, over $70 \%$ have boards with a majority of "outside" directors. ${ }^{3}$ In recent years these boards have shown a willingness - some might say enthusiasm - for firing their CEOs. In 2000 alone, $20 \%$ of the largest U.S. companies replaced their top executives. ${ }^{4}$

'Board of Governors of the Federal Reserve System, Flow of Funds Accounts of the United States, Mar. 7, 2002, at 103, Table B.102, Balance Sheet of Nonfarm Nonfinancial Corporate Business (showing balance sheet assets of $\$ 17.5$ trillion). Book value may significantly understate real value as it fails to account for inflation, investments in human capital, some forms of intellectual property, and so forth.

${ }^{2}$ See DEL. CODE ANN. tit. 8, \$141(a) (2001) ("The business and affairs of every corporation organized under this chapter shall be managed by or under the direction of a board of directors ....").

${ }^{3}$ See John C. Coates IV, Measuring the Domain of the Mediating Hierarchy: How Contestible Are U.S. Public Corporations?, 24 J. CORP. L. 835, 844 (1999) (describing study that found, in a sample of approximately 1,000 large public firms, that only $30 \%$ did not have a majority of independent directors). Id. However, large companies account for the lion's share of corporate economic activity. For example, the fifty largest companies in the United States, as measured by revenues, also accounted for $53 \%$ of all revenues and $55 \%$ of private-sector employment. Id. at 848.

4Anthony Bianco \& Louis Lavelle, The CEO Trap, BUS. WK., Dec. 11, 2000, at 86 (reporting that 39 of the largest 200 U.S. companies replaced their CEOs in 2000, and that two-thirds of all major companies had replaced their CEOs at least once since 1995). 
In today's business environment, the buck ultimately stops in the boardroom, not the comer office.

Of course, some contemporary observers might object instead, "[i]t's still wrong to say directors control the corporation. It's the shareholders who control the firm, because the shareholders elect the directors." In recent years there indeed has been a significant increase in shareholder activism. However, it seems premature to announce that Berle and Means can now rest easily in their graves, because share ownership and control have become fused in the modern corporation. ${ }^{5}$ Despite the rise of institutional investors like pension funds and mutual funds, share ownership remains dispersed in most large public companies-it is rare to find a single shareholder owning even $5 \%$ of a big firm. As a result, shareholders remain rationally apathetic. Rather than become involved in corporate governance, if they are unhappy they do the "Wall Street walk," and sell their shares. This means that, as a practical matter, the average corporate director does not need to worry too much about being ousted in a proxy battle. Nor, given the expense and difficulty of a hostile tender offer in the era of the poison pill and the staggered board, does she need to worry much about losing her job in a hostile takeover.

For better or worse, boards of directors enjoy enormous control over tens of trillions of dollars of what is mostly other people's money. Why have we entrusted directors with those tens of trillions? This question is one of the most fundamental mysteries of modern corporate governance. It is a mystery because if we look at the external incentives directors face-the actual rewards and punishments they receive-the average director seems to have remarkably little reason to spend much time or effort laboring on the firm's behalf.

\section{ON THE DEFICIENCIES OF DIRECTORS' EXTERNAL REWARDS}

It was once the tradition for corporations to pay a flat fee for directors' services. ${ }^{6}$ This approach paid a director the same amount whether the corporation did well or did poorly, and whether the board did a good job or a bad one. In other words, the traditional compensation structure did not offer a lot of financial reward for the director who did a good job. In response to this perceived problem, it has become common practice in

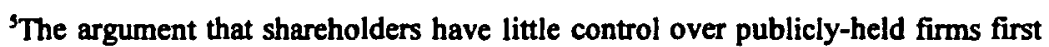
gained prominence in 1932, with the publication of Berle and Means' classic argument that "ownership" had become separated from "control" in the modern firm. See ADOLF A. BERLE, JR. \& GARDINER C. MEANS, THE MODERN CORPORATION AND PRIVATE PROPERTY (1933).

${ }^{6}$ ROBERT C. CLARK, CORPORATE LAW 108-09 (1986).
} 
recent years for many corporations to pay some or all of their directors' fees in the form of stock or stock options. This development has been applauded by some corporate law scholars as a means of "bonding" directors' financial interests with those of the other shareholders.'

Closer analysis suggests, however, that this bonding is mostly illusory. For example, the compensation that directors of public corporations typically receive for their services often is not terribly significant, at least from their perspective. The typical large public corporation will pay board members an annual fee that can be measured, whether paid in cash or in stock, in the tens of thousands of dollars. Although that may sound like a lot of money to the average working person, it is not a lot of money to the average successful executive, especially the average successful business executive. The CEO of a typical U.S. firm might be paid millions or even hundreds of millions of dollars annually in salary, bonus, stock, and stock options. ${ }^{8}$ In comparison, any fees received for sitting on the board of another firm, as many CEOs do, seem like pocket change.

Paying directors with shares of stock is also a questionable remedy because, even when those shares account for a significant portion of the director's income or wealth, whether the shares go up or down in value is likely to be only tangentially related to the individual director's own efforts. The health of the broader economy, changes in consumer tastes, shifting commodity prices, and increasing or decreasing competition have far more impact on stock prices. Also, a share price increase is a public good that invites free riding. Why should an individual director knock herself out to raise the market price of the company's stock, when all the other members of the board (not to mention all the other shareholders) are going to share the benefit??

Considering financial rewards alone, whether paid in cash or in shares, directors seem to have little reason to break a sweat in the boardroom. Rather, we would expect them to shirk to approve what is on the agenda, take their fees, and go home. But we do not need to rely on carrots, alone, to motivate directors. There is also the possibility of sticks.

${ }^{7}$ See, e.g., Charles M. Elson, The Duty of Care, Compensation, and Stock Ownership, 63 U. CIN. L. REV. 649, 652-53 (1995) ("Corporations should pay their directors' annual fees in company stock").

${ }^{8}$ See Bianco \& Lavelle, supra note 4, at 88 (reporting average CEO compensation in 1999 that exceeded $\$ 12$ million annually).

${ }^{9} \mathrm{~A}$ third difficulty associated with stock incentive-based compensation is that it can encourage directors to take actions that can raise share price in the short run effectively, while harming the firm's long-run prospects. Accounting fraud provides an extreme example of this phenomenon. See infra text accompanying note 52 (discussing this problem). 
Thus, one might argue that corporate directors have incentive to do a good job not because they hope for a reward if they do, but because they fear they will be punished if they do not when a court finds them personally liable to the firm for breach of fiduciary duty.

\section{ON THE DEFICIENCIES OF DIRECTORS' EXTERNAL PUNISHMENTS}

Readers who are experienced corporate judges and lawyers are, of course, likely laughing. For those who do not see the humor in the suggestion that directors might be driven by fear of personal liability, a short primer on the nature and enforcement of directors' fiduciary duties may be instructive.

In brief, directors' fiduciary duties come in two basic flavors: the duty of care and the duty of loyalty. ${ }^{10}$ These two flavors reflect the fact that when people misbehave, they tend to do so in one of two common ways. First, they may misbehave by acting like fools (acting carelessly). Second, they may misbehave by acting like knaves (acting dishonestly).

The duty of loyalty is designed, in theory, to address the knavishness problem. Put more bluntly, the duty of loyalty addresses the possibility that directors might try to steal from their firms. The duty of loyalty discourages such theft by imposing liability on directors who enter unfair "interested transactions," meaning transactions between the firm and the director (or between the firm and some individual or entity in which the director has a personal interest) under terms that are unfavorable to the firm. It also penalizes directors who steal from their firms by "taking corporate opportunities" - business opportunities that, for a variety of reasons, ought to have gone to the firm.

A problem arises, however, when we look to the remedy that is normally granted when a court finds that a director has violated the duty of loyalty. When a director has participated in an unfair transaction with the firm, the usual remedy is to make the director pay a fair price. If the director has violated the duty of loyalty by taking a corporate opportunity,

\footnotetext{
${ }^{10} \mathrm{Most}$ corporate law fiduciary cases revolve around these two forms of duty. In addition, in extreme situations a director might be found to have violated the duty not to "commit waste." Under the waste doctrine, directors can be held liable for corporate transactions when the consideration received by the firm is "so disproportionately small as to lie beyond the range at which any reasonable person might be willing to trade." Lewis $v$. Vogelstein, 699 A.2d 327, 336 (Del. Ch. 1997) (discussing waste standard). More recently, the Delaware Supreme Court has suggested that directors also have a fiduciary duty to make accurate disclosures to shareholders, although the nature and consequences of this duty remain undeveloped. See Malone v. Brincat, 722 A.2d 5, 9-10 (Del. 1998).
} 
she must return to the firm any profits made from that opportunity. In sum, the remedy for a breach of the duty of loyalty is to make the director give back whatever she has stolen from the firm.

This is not the kind of threat to strike terror into a larcenous heart. As any parent can tell you, if the only punishment a child receives for stealing from the cookie jar is that she has to give back the cookies if caught, you can expect a lot of stolen cookies. For similar reasons, it is easy to suspect that the threat of being held liable for breach of the duty of loyalty is not the sole, or even the principal, reason most corporate directors do not steal from their firms. Although the duty of loyalty on first inspection deters corporate directors from stealing, closer analysis suggests that as a practical matter the rule does not have much bite.

This toothlessness is even more obvious in the case of the director's duty of care. In theory, corporate directors owe their firms a duty to manage those tens of trillions of dollars of corporate assets with the care of a reasonably prudent person. In practice (as any law student who has taken a class in corporations knows) the duty of care is ameliorated - some might say eviscerated - by a doctrine known as the business judgment rule. The business judgment rule is a legal presumption that a director has, in fact, met the standards of the duty of care. This presumption can only be overcome if a plaintiff can show that the director did not act "on an informed basis," "in good faith," or "in the honest belief that the action taken was in the best interests of the company."11 The last two elements (good faith and honest belief) usually go unchallenged in any case that does not involve the sort of conflict of interest that gives rise to a loyalty question. ${ }^{12}$ As a result, whether the business judgment rule applies to a particular director usually turns solely on whether that director bothered to "inform" herself before acting. Furthermore, the test for whether a director is uninformed is not mere negligence, but gross negligence. ${ }^{13}$

The business judgment rule accordingly allows a director who makes even a minimal effort to become "informed" to make foolhardy decisions all day long, without fear of liability. And what about the rare case of the director who is found to have been uninformed? Even then, other barriers protect directors from personal liability. For example, Delaware corporation law allows corporations to adopt charter provisions that eliminate

\footnotetext{
"Smith v. Van Gorkom, 488 A.2d 858, 872 (Del. 1985) (quoting Aronson v. Lewis, 473 A.2d 805, 812 (Del. 1984)).

${ }^{12}$ See, e.g., id. at 873 (noting in duty of care case focusing on whether directors were informed that "there were no allegations of fraud, bad faith, or self-dealing" and as a consequence "considerations of motive are irrelevant to the issue before us").

${ }^{13}$ Id. (quoting Aronson, 473 A.2d at 812 ).
} 
director liability for breach of the duty of care. ${ }^{14} \mathrm{~A}$ number of large corporations have taken advantage of this provision. In firms that have not, if a lawsuit claiming breach of director care is brought, the odds are that it will be settled, and either an insurance company will foot the bill (under a director's liability policy) or the corporation itself will pay (under an indemnity provision). ${ }^{15}$

Taking these factors together, it is only a slight exaggeration to suggest that a corporate director is statistically more likely to be attacked by killer bees than she is to have to ever pay damages for breach of the duty of care. This reality of business life is well-recognized among corporate scholars. ${ }^{16}$ In response, several have suggested in recent articles that corporate directors exercise care not because they fear legal sanctions, but because they fear what might be called "social sanctions"- because they do not want to lose face, acquire a bad reputation, or become the object of disapproving glances and cutting remarks. ${ }^{17}$

This is an intriguing argument. There are several reasons, however, to suspect that the fear of social sanctions may provide only a weak incentive for exercising care for most directors in most circumstances. While directors involved in more-spectacular corporate crimes (for example, a massive accounting fraud) can suffer unpleasant notoriety, allegations of garden-variety negligence or conflict of interest are far less likely to attract media attention. In most cases neither the general public, nor a director's immediate social circle, would know (much less care) whether she was doing a good job as a fiduciary. Similarly, it can be difficult for others to judge whether an allegation of breach of fiduciary duty has merit, or is simply an attempt to extract money from the director's liability insurer through the threat of a "strike suit." For these and other

${ }^{14}$ DEL. CODE ANN. tit. 8, $\S 102(b)(7)(2001)$.

${ }^{15}$ See Margaret M. Blair \& Lynn A. Stout, Trust, Trustworthiness, and the Behavioral Foundations of Corporate Law, 149 U. PA. L. REV. 1735, 1790-91 (2001) (discussing these and other barriers to director liability).

${ }^{16} \mathrm{An}$ interesting question is whether it is also well-recognized among corporate directors. To the extent that it is not, we do not need to rely so heavily on altruism as an incentive for directors to behave like faithful fiduciaries. See Lynn A. Stout, In Praise of Procedure: An Economic and Behavioral Defense of Smith v. Van Gorkom and the Business Judgment Rule, 96 Nw. U. L. REV 675, $692 \mathrm{n.61}$ (2002) (discussing possibility that directors systematically overestimate the possibility of personal liability).

${ }^{17}$ See, e.g., Melvin A. Eisenberg, Corporate Law and Social Norms, 99 ColuM. L. REV. 1253 (1999); Edward B. Rock, Saints and Sinners: How Does Delaware Corporate Law Work?, 44 UCLA L. REv. 1009 (1997); David A. Skeel, Jr., Shaming in Corporate Law, 149 U. PA. L. REV. 1811 (2001). 
reasons, ${ }^{18}$ external sanctions-including not only legal sanctions, but also social sanctions-are inadequate to explain why a purely self-interested director would take her fiduciary duties seriously.

\section{ON THE POSSIBILITY \\ OF OTHER-REGARDING DIRECTORS}

That brings us back to the fundamental mystery of the corporate board. Given directors' apparent lack of external incentives to do a good job-the absence both of good carrots, and of effective sticks-why do we trust directors to manage tens of trillions of dollars of corporate assets? And, why do they seem to mostly live up to our trust? Or at least, live up to it well enough that the U.S. system of corporate governance often is held up as a model for the rest of the world, ${ }^{19}$ and board failures of the sort recently observed at Enron and Worldcom can still, one hopes, be viewed as the highly-publicized exceptions rather than the rule. ${ }^{20}$

The discussion below explores this basic mystery. It begins with the assumption that the institution of the corporate board of directors works. Put differently, it assumes that the institution of the corporate board of directors performs some useful economic function. (If it does not, we have an even greater puzzle to solve-why boards endure as a universal feature of public corporations.) It then explores the hypothesis that the institution of the corporate board works because we do not, in fact, rely on external incentives and pressures, alone, to motivate directors to do a good job. We also rely on internal pressures -including such internal pressures as a director's sense of honor; her feelings of responsibility; her sense of

${ }^{18}$ For example, it is difficult to explain why a purely self-interested third-party observer would bother to impose social sanctions on a careless director. (It is perhaps worth noting that, even in high-profile cases, white-collar corporate criminals often seem to keep their friends, families, and country club memberships. See Edward Cohn, The Resurrection of Michael Milken, in THE AMERICAN PROSPECT, Mar. 13, 2000, at 27 (discussing case of Michael Milken, who served 22 months in jail and is now a sought-after speaker, author, and philanthropist)). It is also worth asking why a purely self-interested director would care about others' opinions, especially if she was retired or close enough to retirement not to worry about future job prospects. See Blair \& Stout, supra note 15, at 1749 \& n.27, 1793 97, and 1801-02 (discussing this and other critiques of the social sanctions argument).

${ }^{19}$ See John Rossant et al., The Corporate Cleanup Goes Global, Bus. WK., May 6, 2002, at 80 ("For decades... powerful fund managers have lectured the Europeans and the Japanese about the need to run their corporations according to the transparent U.S. model.").

${ }^{20}$ See, e.g., John A. Byrne et al., How To Fix Corporate Governance, Bus. WK., May 6, 2002, at 69, 70 ("In many ways, Enron and its dealings with Arthur Andersen are an anomaly, a perfect storm where greed, lax oversight, and outright fraud combined to unravel two of the nation's largest companies.") 
obligation to the firm and its shareholders; and, her desire to "do the right thing."

Of course, it has become tremendously unfashionable to talk about these kinds of internal pressures in corporate governance scholarship. This may be due in part to the defining influence that economic analysis has had in recent years on the legal culture in general, and on corporate law scholars in particular. ${ }^{21}$ Economic analysis has little use for such concepts as honor, trustworthiness, or duty. This is because economic analysis generally begins by assuming that people behave like homo economicus - that they are perfectly rational and purely self-interested actors.

Yet if this were true of corporate directors-if directors did in fact always behave like homo economicus - the institution of the board of directors of the public corporation would never have evolved in the way that it has. Indeed, it might never have evolved at all. Rational investors would never cede control of tens of trillions of dollars of assets to purely self-interested boards, given the tissue-paper thin protection offered by the rules of fiduciary duty, and the limits of social sanctions.

Accordingly, if we want to understand how boards of directors work, we need to develop a better understanding of the sorts of internal pressures encompassed by terms like "honor," "integrity," "trustworthiness," and "responsibility." Yet how can we gain a firm grasp on such soft and slippery concepts? The neoclassical economic literature offers little guidance. Guidance is available, however, if we expand the search to include the broader social sciences, including psychology, sociology, biology, and anthropology.

There is a large body of literature in the broader social sciences on the phenomenon that will be described below, in general terms, as "otherregarding" behavior. ${ }^{22}$ As this label suggests, this literature examines instances in which people behave as if they care about something other than their own payoffs. This "other" might be the welfare of another person, or the fate of an institution like "the firm," or even an abstract principle such as "do the right thing." The point is that the evidence demonstrates that

\footnotetext{
${ }^{21}$ For some examples of this influence, see FRANK H. EASTERBROOK \& DANIEL $R$. FISCHEL, THE ECONOMIC STRUCTURE OF CORPORATE LAW (1991); FOUNDATIONS OF CORPORATE LAW (Roberta Romano ed., 1993).

${ }^{22}$ See, e.g., Frances FuKUYAMA, TRUST: THE SOCIAL VIRTUES AND THE CREATION of ProspertTy (1995); ElliotT SOBER \& DAVID SLOAN WILSON, UNTO OTHERS: THE EVOLUTION AND PSYCHOLOGY OF UNSELFISH BEHAVIOR (1998); BEYOND SELF-INTEREST (Jane J. Mansbridge ed., 1990).
} 
people sometimes behave altruistically — as if they care about others, and not only about themselves.

\section{SOME EVIDENCE OF OTHER-REGARDING BEHAVIOR FROM SOCIAL DILEMMA GAMES}

As an example, let us consider the lessons that can be drawn from studies of human behavior in a kind of experimental game called a social dilemma. Social scientists have shown an enduring fascination with social dilemma studies - over the past four decades, hundreds of studies have been conducted..$^{23}$ As a result, and in contrast to other investigations of other-regarding behavior that are either anecdotal or report the results of idiosyncratic experiments, the social dilemma literature offers a formal, comprehensive, and particularly persuasive and useful source of data on altruistic behavior. This data source offers some important insights into the nature and incidence of altruistic behavior.

To appreciate these insights, we must first take a closer look at a typical social dilemma game. In brief, these games are designed to place players in a position where their self-interest conflicts with the interests of other players. This is done by presenting subjects with a choice of strategies: either "cooperate" in a way that benefits the other members of the group, or "defect" and maximize your own personal payoffs. The experiment is structured, however, so that if all the subjects behave selfinterestedly and defect, they end up worse off than if all had cooperated. (As readers who are familiar with rational choice theory may suspect, the social dilemma game is based on and named after the famous Prisoners' Dilemma of game theory.)

A common form of social dilemma experiment is called the "Give Something" game. In this game, a group of subjects (say, four people) are brought together, and each subject is given a certain amount of money as an initial stake (say, \$10). The subjects are then told that they must chose between either keeping their $\$ 10$ for themselves, or contributing some or all of it to a common pool. They are also told that any money donated into the common pool will be multiplied by some factor (for example, tripled)

${ }^{23}$ See generally Robyn M. Dawes, Social Dilemmas, 31 ANN. REV. PSYCH. 169, $182-$ 88 (1980) (reviewing results of numerous studies); Robyn M. Dawes et al., Cooperation for the Benefit of Us-Not Me, or My Conscience, in BEYOND SELF-INTEREST, supra note 22, at 97 (reviewing studies); Robyn M. Dawes \& Richard H. Thaler, Cooperation, 2 J. ECON. PERSP. 187 (1988) (summarizing studies); David Sally, Conversation and Cooperation in Social Dilemmas: A Meta-Analysis of Experiments from 1958 to 1992, 7 RATIONALITY \& SOC'Y 58 (1995) (summarizing over 100 studies done between 1958 and 1992). 
and then redistributed back to the subjects. However, the money in the pool will be distributed back in equal shares to each of the subjects in the game, whether or not they chose to donate in the first place.

How would homo economicus play the Give Something game? Homo economicus would say to herself: "No matter what the others do, I should keep my ten bucks. If I donate it, it will be tripled to $\$ 30$, but I will get only one-fourth of that back, which is $\$ 7.50$. So I will keep my $\$ 10$, and hope to share as well in one-fourth of any amount that ends up in the pool if my fellow players are foolish enough to donate."

Of course, if everyone thinks this, everyone keeps her $\$ 10$. No money goes into the pool and no money gets multiplied. Conversely, if everyone behaves altruistically and donates her money, the pool of $\$ 40$ will become a pool of $\$ 120$, and each of the four subjects will get $\$ 30$ back-a considerably better payoff. Unfortunately, if the players are rational and selfish, this will never happen. This is because, while cooperation produces a better outcome for the group, defection always produces the best result for the individual player. No matter what her fellow players do, the individual player always maximizes her payoff by defecting, instead of cooperating.

Homo economicus accordingly would never choose to donate to the common pool in a one-shot social dilemma. What do real people do? There have been literally hundreds of experiments reported in the literature. ${ }^{24}$ With remarkable consistency, these studies conclude that real people cooperate. In fact, they cooperate a lot. On average, participants in social dilemmas contribute about $50 \%$ of their initial stake to the common pool. ${ }^{2 s}$

What does this tell us about human behavior? The first thing it tells us is that people frequently behave as if they care about others' payoffs, and not just their own. Researchers have gone to rather extraordinary lengths to ensure that the subjects in a social dilemma understand that they will receive no extrinsic reward or recognition for cooperating. For example,

\footnotetext{
${ }^{24}$ See, e.g., sources cited supra note 23.

${ }^{25}$ See, e.g., Dawes \& Thaler, supra note 23, at 189 (observing that subjects contribute an average of $40-60 \%$ in social dilemma contribution games); Sally, supra note 23 , at 62 (reporting mean cooperation rate of $50 \%$ for sample of over 100 studies).

Because most reported social dilemma experiments use undergraduate and graduate students as subjects, such results can be critiqued on the grounds their behavior may not be typical of other populations. However, a recent cross-cultural study of social dilemma games among nonstudents in a variety of cultures found similar patterns of behavior. See Joseph Henrich et al., In Search of Homo Economicus: Behavioral Experiments in 15 Small-Scale Societies, 91 AM. ECON. REV. 73, 74 (2001) (reporting cooperation rates ranging from $26 \%$ to $58 \%$ in seven very different societies.)
} 
in many experiments, the subjects are strangers who are told that they will play the game only once and who are assured that their choice of strategy will remain a secret, unknown to either the experimenter or their fellow players. $^{26}$ This protocol eliminates any fear of social disapproval or retaliation. Experimenters have also "debriefed" subjects after the game is played to determine whether they truly understood the payoff function in the game, and found that the players did in fact recognize that cooperation reduced their own payoffs. ${ }^{27}$ In other words, the players recognized that cooperation was an altruistic act.

Social dilemma experiments accordingly demonstrate, rather conclusively, that people often behave altruistically. This is not to say that they necessarily feel altruistic. One can imagine any number of psychological mechanisms that might lead someone to conclude that she is better off, subjectively, if she sacrifices to help others. For example, altruistic behavior might be motivated by a desire to avoid unpleasant feelings of guilt, by a desire to conform to some internalized notion of proper role or deportment, or by the fear of divine retribution. The point is that, whatever these subjective motivations are, they are subjective. Objectively speaking, when one makes a sacrifice to make others better off, one makes oneself worse off. Indeed, this is the very definition of sacrifice.

Social dilemma studies accordingly do not prove psychological altruism (that people truly care about others' welfare). They do, however, offer compelling evidence of behavioral altruism (people often act as if they care about others). A variety of theories can be advanced to explain why people sacrifice for others, and I suspect each may be correct for some persons, and some circumstances. Luckily, we do not need to understand what motivates altruistic behavior to observe the behavior itself. Even better, we do not need to understand what motivates altruistic behavior to encourage it.

This is because a second important lesson of the social dilemma literature is that altruistic behavior is not only common, it is easy to manipulate. Experimenters have found that they have a remarkable degree of control over whether or not people cooperate in such games. By manipulating certain variables, social scientists have been able to produce cooperation rates as low as $5 \%$ (an almost complete absence of altruism) ${ }^{28}$ Conversely, they have also been able to produce cooperation rates as high

\footnotetext{
${ }^{26}$ Sally, supra note 23 , at $65,67$.

${ }^{27}$ See, e.g., Henrich et al., supra note 25 , at 74.

${ }^{28}$ Sally, supra note 23 , at 62,65 .
} 
as $97 \%$ (nearly universal altruism). ${ }^{29}$ It is important to bear in mind that in all of these games, the external payoffs favored defection.

Such findings command attention. If we can understand the factors and variables that tend to promote other-regarding behavior among experimental subjects in the laboratory, perhaps we can also begin to understand the factors and variables that are likely to promote otherregarding behavior in the boardroom. In other words, perhaps we can harness the phenomenon of other-regarding behavior, and encourage directors of public corporations to behave even more altruistically than they already do in looking after the firm's interests.

To explore this possibility, the discussion below examines three variables that have been found to be very powerful, statistically speaking, in predicting cooperative behavior in social dilemmas. It also speculates as to what these findings might tell us about how we can best encourage corporate directors to serve as careful, loyal fiduciaries.

\section{SOCIAL CONTEXT AS A DETERMINANT OF ALTRUISTIC BEHAVIOR}

Let us begin by considering the variable that, perhaps more than any other, seems to influence individuals' decisions about whether or not to cooperate in a social dilemma. ${ }^{30}$ This critical variable is something that might be called "social context." Social context can be defined as an amalgam of signals we receive about such matters as what other people expect, what other people need, and what other people are likely to do.

Experimenters have found that such social variables seem to have a significant impact on a subject's decision whether or not to cooperate in a social dilemma game. For example, researchers have found that cooperation rates are influenced by subjects' perceptions of how much their cooperation benefits others (the greater the perceived benefit to others, the greater the incidence of cooperation); ${ }^{31}$ by whether the subjects feel a sense of common social identity with each other (players divided into random groups cooperate more with members of their "in-group" than with

\section{${ }^{29}$ Id.}

${ }^{30}$ See id. at 77 (concluding from statistical analysis of over 100 reported studies that a variety of social variables that should be irrelevant to purely-self interested subjects are significantly correlated with cooperation rates, while, except for considerations of personal cost, "[a]ll the other variables that should affect a selfish decider either are not meaningful or have the opposite sign [of statistical significance]").

${ }^{31} I d$. at 79. 
members of their "out-group"); ${ }^{32}$ and by whether the subjects expect their fellow players to cooperate or defect (players who believe their fellows are going to cooperate, are far more likely to cooperate themselves). ${ }^{33}$

It is important to note that homo economicus would be utterly indifferent to such matters if they did not change his own payoffs. Homo sapiens, however, seems to find social variables compelling. Judging from our behavior, we are extremely sensitive to the signals we receive about the expectations, needs, attitudes, identities, and likely behavior of the people around us.

As an example of this sensitivity, consider a particular variable that seems to be especially powerful in predicting cooperation rates, and, moreover, that may be especially relevant to understanding the behavior of corporate directors. This variable is the experimenter's requests. In some social dilemma games, researchers have not only presented the subjects with a choice of cooperating or defecting, but they also have requested that the subjects adopt one strategy or the other. Readers will probably not be shocked to learn that when the experimenter in a social dilemma game asks subjects to cooperate subjects are more likely to cooperate. Similarly, when the experimenter suggests the subjects defect, subjects are more likely to defect. ${ }^{34}$

This result is surprising only when one stops to recall that a purely self-interested subject would pay no attention to the experimenter's requests in a social dilemma game, because these requests do not change the payoff structure of the game. Players always maximize their personal payoffs by defecting, and the rational and self-interested actor should recognize this and defect. Nevertheless, real people playing social dilemma games appear to pay very close attention to the experimenter's desires, so much so that they will change their behavior significantly in response to mere hints about what the experimenter wants.

A good example of this sensitivity can be found in the results of a social dilemma experiment in which the experimenters told their subjects that they were going to play something called the "Community Game." On average, subjects in this experiment cooperated $70 \%$ of the time. Then, the experimenters changed the name of the game to the "Wall Street Game."

${ }^{32}$ Sally, supra note 23 , at 78-79.

${ }^{33}$ See Dawes, Social Dilemmas, supra note 23, at 187.

${ }^{34}$ Sally, supra note 23, at 64-65, 74. 
Subjects asked to play the Wall Street Game only cooperated $33 \%$ of the time. ${ }^{35}$

These results imply that you do not always need to threaten directors with sticks or bribe them with carrots to get them to behave like careful and loyal fiduciaries. To the contrary, directors might be inclined to behave in an other-regarding fashion simply because a respected authority asks them to do so. This observation supports the views of corporate theorists who argue that judicial opinions in fiduciary duty cases can encourage directors to behave like reliable fiduciaries not primarily by threatening them with the prospect of personal liability, but by expressing and reinforcing social norms of careful and loyal fiduciary behavior. ${ }^{36}$ As Professor and former Delaware Chancellor William Allen has put it, judicial opinions influence the behavior of directors as "moral beings" by "express[ing] community ideals" about their proper deportment and role. ${ }^{37}$ If directors view judges as respected authorities similar to the experimenter in a social dilemma game, this "expressive" technique may be effective. Judges can speak loudly, and leave the big stick at home. ${ }^{38}$

This human sensitivity to social signals about appropriate behavior also suggests that perhaps we should be more troubled by a recent development that has often been assumed to promote better director performance. This development is the trend toward paying directors' fees not in cash but in the form of shares of the company's stock. ${ }^{39}$ On one hand, this compensation scheme gives directors an economic interest in the price of the company's shares, and so a personal motive to increase share price. This selfish motive is likely to be weak, however, given the

\footnotetext{
${ }^{35}$ Lee Ross \& Andrew Ward, Naive Realism in Everyday Life: Implications for Social Conflict and Misunderstanding, in VALUES AND KNOWLEDGE 103 (Edward S. Reed et al. eds., 1996).

${ }^{36}$ See sources cited supra note 17; William T. Allen, The Corporate Director's Fiduciary Duty of Care and the Business Judgment Rule Under U.S. Corporate Law, in COMPARATIVE CORPORATE GoVERnANCE: THE STATE OF THE ART AND EMERGING RESEARCH 307, 328 (Klaus J. Hopt et al. eds., 1998).

${ }^{37}$ Id. at 329.

${ }^{38}$ It should be noted that many commentators who argue that corporate law works primarily by influencing norms presume these norms are enforced primarily through social sanctions imposed by third parties. See, e.g., Rock, supra note 17, at 1013-14 (saying that "[t]he story I tell in this Article is very much a story of how a small community imposes formal and informal, legal and nonlegal, sanctions on its members"); Skeel, supra note 17 (discussing third-party shaming). The social dilemma evidence suggests, however, that third party sanctions are reinforced and perhaps not even necessary if the norm is expressed by a respected authority, and then becomes "internalized." See Blair \& Stout, supra note 15, at $1749 \&$ n.27, 1796 (discussing internalization versus third party enforcement).

${ }^{39}$ See supra text accompanying note 7.
} 
disconnect between any individual director's efforts and overall stock performance. $^{40}$ And by emphasizing self-interest, share-based compensation schemes may inevitably send a signal that we expect directors to behave in a selfish fashion in the boardroom. This signal could become a self-fulfilling prophesy. By treating directors as entirely selfinterested, we increase the odds that they will actually behave this way. The net result might be an overall decline in the quality of directors' performance, if their altruistic motivations are undermined more than their selfish motivations are reinforced.

If this possibility seems far-fetched, consider the results of a recent field study undertaken at six day-care centers. In this study, the experimenters set out to determine what would happen if the day-care centers announced that parents who arrived late to pick up their children were, for the first time, subject to a fine. ${ }^{41}$ The homo economicus model would predict that imposing a fine would decrease the incidence of late arrivals, because it increases the cost of tardiness. Yet the experimenters observed the opposite result. After the fine was announced, parents began arriving later more frequently than before. ${ }^{42}$ One possible explanation is that the fine signaled that it was socially acceptable and possibly expected that parents would arrive late. This encouraged parents to adopt a more self-interested calculus that did not include the cost, in terms of inconvenience, their tardiness imposed on the childcare providers at the center. ${ }^{43}$ The net result was a lower perceived "cost of lateness," despite the new fine. ${ }^{44}$

\section{Personal Cost as a Determinant OF ALTRUISTIC BEHAVIOR}

Such empirical results obviously are inconsistent with the homo economicus model of purely self-interested behavior. However, those who are fans of rational choice analysis need not despair. There is a second

${ }^{40}$ See supra text accompanying note 8.

${ }^{41}$ Uri Gneezy \& Aldo Rustichini, A Fine is a Price, 29 J. LEGAL STUD. 1 (2002).

${ }^{42} I d$. at 3.

${ }^{43}$ Id. at 13-15.

"There is a rapidly-expanding literature on this phenomenon, which is called "crowding out." See, e.g., Bruno S. Frey \& Reto Jegen, Motivation Crowding Theory: A Survey of Empirical Evidence, University of Zurich Working Paper No. 245, January 2000, downloadable at http://papers.ssm.com/sol3/papers.cfm?abstract_id=203330. The phrase "crowding out" finds its origins in the notion that if you pay or penalize someone for doing something, they will focus on their own rewards and punishments in a fashion that "crowds out" other-regarding motivations. 
variable that has proven significant in predicting cooperation rates in social dilemma games that is far more "economic" in flavor. This second variable is the personal cost of altruistic behavior to the actor.

It is a common finding in the social dilemma literature that, as the cost of cooperation to the individual player rises, the incidence of cooperative behavior tends to fall. ${ }^{45}$ In other words, people are more inclined to behave "nicely" when it does not cost them too much. In considering the significance of this finding, it is important to bear in mind that any degree of altruistic cooperation in a social dilemma is contrary to the homo economicus model. Thus social dilemma studies demonstrate that people are far more altruistic than neoclassical economic theory assumes. Yet even as subjects in social dilemmas demonstrate a willingness to sacrifice to benefit others, self-interest seems to play an ongoing role in explaining their behavior.

What does this result tell us about the behavior of corporate directors? Most important, it tells us that if we want directors to do a good job of looking out for the interests of the firm and its shareholders, it is essential to make sure that "doing a good job" is not too personally costly to the directors. For example, corporate law is sensible in providing directors with a right to be indemnified for expenses they incur serving the interests of the firm, such as the expenses associated with attending meetings or hiring consultants or outside counsel for expertise and advice. If directors had to pay for these expenses out of their own pockets, social dilemma studies suggest that they might balk at making such a large sacrifice, even if the social context supports altruistic behavior. Similarly, the social dilemma evidence provides support for the idea that we can improve corporate governance in firms where the $\mathrm{CEO}$ also serves as chair of the board, by appointing an independent "lead director" who has authority to call meetings and draft agendas. The appointment of a lead director may lower the psychic, political, and administrative costs independents would otherwise incur in questioning the CEO's wisdom, encouraging more independent oversight. ${ }^{46}$

A less obvious but equally important point is that we want to keep a close eye on the opportunity costs associated with being a director, and make sure those costs do not become too large. Serving as a director takes time, and time is a valuable resource. The director who sits on the boards of more than one company, or the director who is also CEO of another firm,

\footnotetext{
${ }^{45}$ Sally, supra note 23 , at 75.

${ }^{46}$ See generally Stout, supra note 16 , at $688-89$ (discussing the importance of lowering directors' personal "cost of confrontation" if we want to encourage effective and independent oversight).
} 
may find time such a valuable and scarce resource that she becomes reluctant to sacrifice much of it to serving the shareholders' interests. Thus, we might expect individuals who have fewer pressing obligations-retirees (or even law professors) - to be more willing to altruistically devote time and attention to overseeing their firms' affairs. This is not to deny that executives and "promiscuous" directors can bring to the boardroom skills, information, and contacts that might be quite valuable. Such contributions carry a price, however, in the form of a risk that the busy director will spend less time, and pay less attention, than a director with fewer demands.

For related reasons, we should be careful about asking directorsespecially outside directors - to take too great a role in managing the firm. Put differently, if we want directors to do a good job, we do not want to ask them to take on too many tasks. This observation is consistent with the way corporate governance is actually practiced in most large firms. Directors generally do not run the business on a day-to-day basis (this job is delegated to executives and employees), but instead serve an oversight or monitoring role. In effect, directors select senior managers and then step aside, intervening only in times of crisis, or on very large issues such as a merger or major refinancing.

This pattern of relative uninvolvement is sometimes offered as proof of director malfeasance, evidence that directors are not working as hard as they should. Such critiques misunderstand the director's role. Because directors' rewards and punishments are only very loosely tied to their performance, ${ }^{47}$ we must inevitably rely on directors' internalized sense of responsibility as their primary if not their sole motive for exercising judgment and care. The empirical evidence suggests that if we place too heavy a burden on such altruistic motivations, they will crumble under the weight.

It thus makes sense for large corporations to rely on professional managers for most decisions, and to limit directors' responsibilities primarily to monitoring. Monitoring is not nearly as demanding or as timeconsuming as managing. Nevertheless, it can be every bit as important. Just as a smoke detector may seem an idle lump of plastic and metal until an actual fire, a board of directors that appears passive most of the time can save shareholders billions of dollars, if it notices and reacts when things go wrong. For example, the directors of Ford Motor Company may have saved the firm's shareholders from much greater losses when, in the wake of falling sales and rising controversy over the safety of the once-popular

\footnotetext{
${ }^{47}$ See supra text accompanying notes 6-18.
} 
Ford Explorer, they ousted former CEO Jacques Nasser. ${ }^{48}$ Conversely, Enron-which suffered from what has been described as "an almost total collapse in board oversight"—disintegrated from unchecked managerial excess. ${ }^{49}$

A related and very important lesson that can be drawn from the social dilemma evidence on the inverse relationship between cooperation and personal cost is that it is essential that we do not rely too heavily on director altruism in situations where a director has a substantial personal interest adverse to the firm. Put differently, when conflicts of interest loom large, director altruism is likely to founder on the rock of self-interest. This suggests, for example, that the traditional distinction between "inside" directors who are employees of the firm, and "outside" or "independent" directors who are not, is sensible. This is not because inside directors are incapable of altruism. Rather, it is because inside directors, as employees, may often have a personal stake in how the board runs the firm, and as a result be subject to pressures of self-interest that outside directors do not face. ${ }^{30}$

For similar reasons, if we want to rely on outside directors to curb the predictably self-interested behavior of inside directors whose prospects for substantial personal loss or gain may undermine their altruistic motivations, outside directors must be truly independent. They should not, for example, be allowed to use their corporate positions to extract from the firm consulting fees, jobs for relatives, or subsidized access to a private jet. A related observation is that corporate law should be extremely suspicious of any "interested" transaction between the firm and its directors. This suspicion should only be tempered—perhaps not by much-in cases where the interested transaction receives the clear approval of the disinterested members of the board. ${ }^{31}$

Finally, recognizing the threat that self-interest poses to director altruism suggests yet another difficulty associated with the modern practice of compensating directors with shares of company stock. If directors are permitted to sell such shares, a conflict of interest is created between the directors and the firm's long-term shareholders, by giving the directors a personal interest in raising today's stock price at the risk of long-term value. The result may be a board that is tempted to "look the other way" as

\footnotetext{
${ }^{48}$ See Joseph B. White \& Norihiko Shirouzo, Backfire: A Stalled Revolution by Nasser Puts a Ford in the Driver's Seat, WALL ST. J., Oct. 31, 2001, at A1.

${ }^{49}$ Byme et al., supra note 20 , at 72.

${ }^{50}$ For example, inside directors obviously have a personal interest that conflicts with the firm's when the board is determining executive compensation.

${ }^{31}$ See DEL. CODE ANN. tit. 8, \$144 (2001).
} 
corporate managers push the envelope in accounting, or even in the extreme, engage in fraudulent accounting practices. Indeed, it has been suggested that stock-based compensation is partly to blame for recent board failures such as the one observed at Enron. ${ }^{52}$ Thus, stock-based compensation is again revealed to be a double-edged sword. It gives directors selfish incentives, but in the process undermines their altruistic motivations.

\section{CHARACTER AS A DETERMINANT OF ALTRUISTIC BEHAVIOR}

The discussion so far has focused on understanding what circumstances are likely to encourage the average person to behave in an altruistic fashion. No analysis of the role of other-regarding behavior in promoting good corporate governance would be complete, however, without mentioning a third factor that has proven important in determining cooperation rates in experimental games. This third factor is something a psychologist might call "personality type." Laypersons might call it "character."

Let us return to the general finding that cooperation rates among U.S. subjects playing social dilemma games average $50 \%$. This average cooperation rate, it turns out, reflects a blend of two strategies people tend to adopt in social dilemma games: either they donate all the money they have been given to the common pool, or they donate none of it. ${ }^{53}$ In other words, subjects in social dilemma games tend to divide into two groups, the "cooperators" who give everything and the "defectors" who give nothing.

Social scientists have investigated whether these patterns of behavior somehow reflect basic personality characteristics. They have concluded that the answer, to some extent, is yes. Although cooperation rates in social dilemmas are highly dependent on social context and considerations of personal cost, people also seem to bring to the experiments a predisposition to either cooperate or defect. ${ }^{54}$

${ }^{52}$ Byme et al., supra note 20, at 71-72 (discussing Enron and arguing that "[t]he tyranny of the daily stock price has led to borderline accounting and in some cases, outright fraud").

${ }^{53}$ See Henrich et al., supra note 25, at 75.

${ }^{54}$ See Blair \& Stout, supra note 15, at 1764-66 (discussing evidence in support of this conclusion); see, e.g., James E. Alcock \& Diana Mansell, Predisposition and Behavior in a Collective Dilemma, 21 J. CONFLICT RESOL. 443 (1977) (noting that people predisposed to cooperate are less influenced by the actions of others); Peter Brann \& Margaret Foddy, Trust and the Consumption of a Deteriorating Common Resource, $31 \mathrm{~J}$. CONFLICT RESOL. $615,622-23$ (1987) (finding that subjects who score high on a scale intended to measure 
The source of such differences in predisposition is an interesting question. Although genetic causes cannot be ruled out, there is considerable evidence to support the claim that a predisposition to behave in an other-regarding fashion is something that is largely acquired through experience. ${ }^{35}$ In other words, a sense of responsibility or obligation toward others is learned. Student subjects in social dilemmas, for example, tend to display higher cooperation rates as they complete more years of education. ${ }^{56}$ Additional indirect support for the learning hypothesis can be found in a recently-published study that examined the results of social dilemma games played in seven small herding, hunting, and agricultural societies located around the globe. ${ }^{57}$ This study reported significant differences among cultures: the average cooperation rate for the Machiguenga of Peru, for example, was only $22 \%$, while the researchers observed a cooperation rate of $58 \%$ (higher than for U.S. subjects) among the Orma of Kenya. $^{38}$ More to the point, researchers also found a strong correlation between cooperation rates and the frequency of cooperation and market exchange in the culture studied. This finding suggests that habits of cooperation may be learned: the more frequently members of a particular society cooperate with others in their daily economic lives, the more likely they are to cooperate with strangers in a social dilemma experiment as well. ${ }^{39}$

What can these findings teach us about boards of directors in the United States? The answer is fairly straightforward. If we want directors of public corporations to act like faithful fiduciaries-if we want them to serve the interests of the firm and its shareholders, even in situations where it is hard to reward them sufficiently when they do or punish them adequately when they do not-one of the most critical things we can do is to exercise care in selecting those who serve as directors.

As noted earlier, social dilemma experiments suggest that almost anyone can be induced to cooperate altruistically, if the social context is

their willingness to trust others also are more likely to cooperate in a social dilemma).

${ }^{55}$ See Blair \& Stout, supra note 15, at 1766-68 (discussing learning); Lynn A. Stout, On the Export of U.S.-Style Corporate Fiduciary Duties to Other Cultures: Can A Transplant Take? (Apr. 30, 2002) (unpublished manuscript on file with the author) (discussing causes of cooperative behavior).

${ }^{36}$ Robert H. Frank, et al., Does Studying Economics Inhibit Cooperation?, 7 J.EcoN. PERSPS. 159, 166 (1993) (stating that "the overall defection rate declines significantly as students progress through school").

${ }^{57}$ Henrich et al., supra note 25.

${ }^{58}$ Id. at 75-76.

${ }^{39}$ See id. at 75-77. 
structured to strongly support altruism, and if payoffs are arranged so that altruistic behavior is not too personally costly. ${ }^{60}$ Yet the evidence also suggests that some people, whether by nature or nurture, are more inclined toward other-regarding behavior than others. These "cooperators" behave altruistically even in situations where the social signals they receive are somewhat mixed, and altruism requires more than a nominal personal sacrifice. In everyday business life, directors often face such situations. Thus, if we want corporate directors to serve an other-regarding role, we should select as directors those individuals who are more inclined toward other-regarding behavior in the first place.

This is not to say that a sense of honor or responsibility is the only quality one should look for in a director. A willingness to serve the interests of others does not, alone, guarantee that a particular individual will do a good job in the boardroom. Knowledge, experience, and business sophistication are also essential. Also, in some cases, an individual can bring to the board business or political contacts that may prove of great value to the firm. In such situations, it may make sense to consider a tradeoff between altruistic sensibilities, and other desirable director attributes.

Nor does the idea that directors ought to behave in an otherregarding fashion address the difficult issue of who, exactly, is the "other" whom directors ought to serve. One of the most fundamental questions in corporate law is what courts mean when they say that directors, as fiduciaries, ought to serve the interests of "the corporation and its shareholders." ${ }^{161}$ Does this mean that the shareholders are the firm-that they are the only group whose interests directors should care about? Or does the notion of "the firm" encompass something larger, so that directors should sometimes consider the interests of managers, employees, creditors, or even the broader community? The debate between the "shareholder primacy" view and "stakeholder" models of the corporation dates back at least seventy years, ${ }^{62}$ and it remains unresolved today. ${ }^{63}$ Yet the debate

${ }^{60}$ See supra text accompanying notes 28-29 (describing how some experiments have produced cooperation rates as high as $\mathbf{9 7 \%}$ ).

${ }^{61}$ See, e.g., Mills Acquisition Co. v. Macmillan, Inc., 559 A.2d 1261, 1280 (Del. 1989) (holding that "[i]t is basic to our law that the board of directors . . . owe fiduciary duties of care and loyalty to the corporation and its shareholders").

${ }^{62}$ See, e.g., Adolph A. Berle, Corporate Powers as Powers in Trust, 45 HARv. L. REV. 1049 (1932) (arguing that directors should serve shareholders); E. Merrick Dodd, For Whom are Corporate Managers Trustees?, 45 HARV. L. REV. 1145, 1148 (1932) (arguing that directors should also serve employees, managers, and the broader society).

${ }^{63}$ See William T. Allen, Our Schizophrenic Conception of the Business Corporation, 14 CARDOZO L. REV. 261, 265-66 (1992) (discussing debate); see also William T. Allen et al., The Great Takeover Debate: A Meditation on Bridging the Conceptual Divide, $69 \mathrm{U}$. 
does not need to be resolved to appreciate the importance of an otherregarding temperament to a fiduciary role. Whatever interests are encompassed in the idea of "the firm," it remains the firm-and not themselves-whom directors are supposed to serve.

So long as this is true, an inclination toward other-regarding behavior-whether described as a sense of honor, a feeling of responsibility, or the desire to "do the right thing"- will remain a desirable quality in a corporate director. To borrow a metaphor from a very experienced director, to do a good job on a board an individual needs an "internal gyroscope"-something that will keep her steady on her course, despite outside pressures to stray. If we want to have effective boards, it is essential to find the individuals who have that internal gyroscope to serve as directors.

How can we find these directors? There are a number of possibilities, but one of the most obvious is to look at a person's history as evidence of her character. Has she lived up to her commitments, even in situations where she did not have to? Has she undertaken activities that demonstrate that she can care about something other than her own payoffs? Has she given evidence, in the past, of a desire and an ability to do the right thing, even when doing the right thing was not personally advantageous, or particularly popular? If the answers to these questions are "yes," then it is this type of person-and not homo economicus-whom you want to invite to join your board.

\section{CONCLUSION}

One of the most important questions in corporate governance is the question of how corporate directors can be best motivated to serve the interests of the firm. Directors of publicly-held companies frequently hold only small stakes in the companies they manage. Moreover, a variety of legal rules and contractual arrangements insulate them from liability for business failures. Why then should we expect them to do a good job?

CHI. L. REV. 1067 (2002) (discussing persistence of debate); D. Gordon Smith, The Shareholder Primacy Norm, 23 J. CORP. L. 277 (1998) (discussing shareholder primacy view); see, e.g., Stephen M. Bainbridge, Director Primacy: The Means and Ends of Corporate Governance, 97 NW. U. L. REV. (forthcoming 2003) (arguing that directors ought to maximize shareholder wealth); Margaret M. Blair \& Lynn A. Stout, A Team Production Theory of Corporate Law, 85 VA. L. REV. 247, 253 (1999) (arguing that directors can and sometimes ought to take the interests of nonshareholder groups into account); Lynn $A$. Stout, Bad and Not-So-Bad Arguments for Shareholder Primacy, 75 S. CAL. L. REV. 1189 (2002) (discussing debate and concluding that arguments for shareholder primacy are relatively weak). 
Conventional corporate scholarship has had great difficulty wrestling with this question, in large part because conventional scholarship adopts the economist's assumption that directors are rational actors motivated purely by self-interest. This homo economicus model of behavior may be fundamentally misleading when applied to corporate directors. The institution of the corporate board is premised on both the expectation and the actual experience of director altruism, in the form of a sense of obligation to the firm and its shareholders.

To understand the proper role and conduct of corporate directors, we must accordingly abandon the homo economicus approach in favor of a model of human behavior that takes account of the empirical phenomenon of altruistic behavior. One potential starting point for such a project can be found in the extensive evidence that has been developed over the past four decades on altruism among strangers in experimental games. This evidence demonstrates that altruistic behavior is in fact quite common. More important, altruistic behavior also is predictable. A variety of factors can reliably increase, or decrease, the incidence of altruistic cooperation observed in experimental games.

We remain at an early stage in our understanding of the determinants of human altruism. One should accordingly be careful in offering concrete proposals for changing corporate law or policy based solely on the results of experimental studies. After all, one of the foremost lessons of such studies is that other-regarding behavior often depends on social context. Social context, in turn, is a complex phenomenon. Until the experiment is tried, one cannot really know whether parents will be more tardy, or less tardy, when the day-care center decides to impose a fine for lateness. Similarly, any proposal for reforming the corporate board perhaps should be "field tested" before it is imposed more broadly.

Nevertheless, there has been enough progress in our understanding of altruistic behavior that there are at least some lessons that should be taken into consideration in thinking about corporate governance. Most important, if we want the social institution of the board of directors to be effective, we should do our best to accomplish three things. First, we should try to ensure that directors receive social signals that will encourage them to adopt an other-regarding, rather than a purely self-interested, perspective - that will convince them that they ought to "do the right thing." Second, we should make sure that doing the right thing is not too personally costly for directors. Third, we should make sure that we pick the sort of people who want to do the right thing in the first place.

Of course, these are lessons that most experienced business people, including most experienced business lawyers, have already learned. Most of us are sophisticated, if not always conscious, observers of human nature. 
The point here is simply that we should pay attention to what we already know. Personal payoffs count. But so do social context and the quality we call "character." 